\title{
A Review of Functional Neuroimaging in People with Down Syndrome with and without Dementia
}

\author{
Funmi Deinde $^{a}$ Jay Kotecha ${ }^{b}$ Lilian Suh Lih Lau ${ }^{c}$ Sagnik Bhattacharyyad \\ Latha Velayudhan ${ }^{\mathrm{a}, \mathrm{e}}$
}

aDepartment of Psychological Medicine, South London and Maudsley NHS Foundation Trust, London, UK; ${ }^{\mathrm{b} C a r d i f f}$ University School of Medicine, University Hospital of Wales, Heath Park, Cardiff, UK; 'Department of Obstetrics and Gynaecology, Sherwood Forest Hospitals NHS Foundation Trust, Mansfield, UK; 'A Academic Psychiatry Division, Department of Psychosis, Institute of Psychiatry, Psychology, \& Neuroscience, King's College London, London, UK; ${ }^{e}$ Academic Psychiatry Division, Department of Old Age Psychiatry, Institute of Psychiatry, Psychology, \& Neuroscience, King's College London, London, UK

\section{Keywords}

Down syndrome $\cdot$ Dementia $\cdot$ Functional neuroimaging

\begin{abstract}
Background: Individuals with Down syndrome (DS) are at high risk of dementia which is difficult to diagnose in DS. Neuroimaging has been identified as a potential tool to aid diagnosis by detecting changes in brain function. We carried out a review comparing functional neuroimaging in DS individuals with and without dementia. Summary: A literature search was conducted using PubMed to identify relevant studies. In DS subjects with dementia, fluorodeoxyglucosepositron emission tomography (PET) studies showed glucose hypometabolism particularly in the parietal and/or temporal regions whilst magnetic resonance spectroscopy studies showed increased myoinositol and decreased $\mathrm{N}$ acetylaspartate. Ligand-based PET studies revealed significant Pittsburgh compound $B$ binding in DS subjects over the age of 40, particularly if they had dementia. Key Messages: Neuroimaging may aid the early detection of dementia in DS; however, further longitudinal studies are required.
\end{abstract}

(c) 2021 The Author(s).

Published by S. Karger AG, Basel

karger@karger.com

www.karger.com/dee

(c) 2021 The Author(s)

Published by S. Karger AG, Basel

Karger ${ }^{\prime \prime}$ -

BOPEN ACCESS

This is an Open Access article licensed under the Creative Commons Attribution-NonCommercial-4.0 International License (CC BY-NC) (http://www.karger.com/Services/OpenAccessLicense), applicable to the online version of the article only. Usage and distribution for commercial purposes requires written permission.

\section{Introduction}

Individuals with Down syndrome (DS) are at an increased risk of cognitive decline and dementia compared to the general population [1]. In particular, those who are aged 40 years and over show an age-related cognitive decline with early memory involvement as well as the presence of amyloid plaques and neurofibrillary tangles deposited throughout the brain [2-4]. These neuropathologic changes are typically pathognomonic for Alzheimer's disease $(\mathrm{AD})$.

The prevalence rates of AD in DS are reported to be of less percentage in $30-39$ year olds, 10 and $25 \%$ in $40-49$ year olds, between 20 and 50\% in 50-59 year olds, and between 30 and $75 \%$ in those aged 60 years and over [5]. This increased risk of AD in DS is thought to be due to the extra copy of chromosome 21. It is this trisomy 21 which leads to an overexpression of the amyloid precursor protein gene which is located on chromosome 21. This in turn leads to the early onset and rapid accumulation of $\beta$-amyloid plaques in the brain [6-8].

Dementia can be difficult to diagnoses in DS for various reasons. For example, the accuracy of DS-specific cognitive tests has been debated as it has been difficult to 
Table 1. FDG-PET studies on DS with and without dementia

\begin{tabular}{|c|c|c|c|c|c|}
\hline Study & Study design & Region of interest & Cohort & Clinical data & Main findings \\
\hline Cutler [18] & Case control & $\begin{array}{l}\text { Right cerebral hemisphere, } \\
\text { frontal lobe, parietal lobe, } \\
\text { temporal lobe, occipital lobe }\end{array}$ & $\begin{array}{l}n=10 \text { nondemented DS } \\
\text { (aged 19-23), } n=2 \\
\text { nondemented DS (aged } \\
41-64 \text { ), } n=2 \text { demented DS } \\
\text { (aged } 41-64), n=14 \text { controls } \\
\text { (aged } 20-35 \text { ) and } n=19 \\
\text { controls (aged 40-60) }\end{array}$ & Not stated & $\begin{array}{l}\text { Age-related declines in brain } \\
\text { metabolism were found in } \\
\text { the middle-aged } \\
\text { (nondemented) DS subjects } \\
\text { and further reductions } \\
\text { observed in the demented } \\
\text { DS subjects }\end{array}$ \\
\hline $\begin{array}{l}\text { Schapiro } \\
\text { et al. [19] }\end{array}$ & Case report & $\begin{array}{l}\text { Right and left hemispheres, } \\
\text { orbital frontal, superior } \\
\text { frontal, precentral, } \\
\text { postcentral, inferior parietal, } \\
\text { occipital cortex, temporal, } \\
\text { basal ganglia, cerebellum, } \\
\text { cingulate, parietal } \\
\text { association/sensorimotor, } \\
\text { lateral temporal association/ } \\
\text { occipital }\end{array}$ & $\begin{array}{l}n=1 \mathrm{DS} \text { (aged } 47 \text { with } \\
\text { autopsy confirmed AD), } n= \\
13 \text { nondemented DS (aged } \\
19-33 \text { ) }\end{array}$ & $\begin{array}{l}\text { PPVT -revised, the block } \\
\text { patterns subtest from the } \\
\text { Hiskey Nebraska tests of } \\
\text { learning aptitude, WISC-R block } \\
\text { design subtest, extended block } \\
\text { design test, digit span, block } \\
\text { tapping, object span, visual } \\
\text { recognition memory }\end{array}$ & $\begin{array}{l}\text { The demented DS subject's } \\
\text { mean hemispheric CMRglc } \\
\text { was } 28 \% \text { less than the group } \\
\text { of } 13 \text { nondemented younger } \\
\text { DS subjects. Marked glucose } \\
\text { hypometabolism evident in } \\
\text { parietal and temporal lobes }\end{array}$ \\
\hline $\begin{array}{l}\text { Schapiro } \\
\text { et al. [4] }\end{array}$ & Case control & $\begin{array}{l}\text { Parietal, lateral temporal, } \\
\text { sensorimotor, occipital }\end{array}$ & $\begin{array}{l}n=20 \text { DS (aged 19-34), } n=5 \\
\text { nondemented DS (aged } \\
45-63), n=4 \text { demented DS } \\
\text { (aged } 45-63 \text { ) and } n=13 \\
\text { controls (aged 22-38) }\end{array}$ & $\begin{array}{l}\text { DSMSE, WISC-R block design } \\
\text { subtest, Extended block design } \\
\text { Test, Hiskey Nebraska block } \\
\text { pattern subtest, design span, } \\
\text { PPVT (revised), Stanford-Binet, } \\
\text { digit span, Block tapping, } \\
\text { Object span }\end{array}$ & $\begin{array}{l}\text { Demented DS showed } \\
\text { glucose hypometabolism } \\
\text { with relatively greater } \\
\text { involvement of parietal- } \\
\text { temporal association } \\
\text { neocortices and relative } \\
\text { sparing of primary } \\
\text { sensorimotor neocortex, } \\
\text { cerebellum, thalamus, and } \\
\text { caudate and lenticular nuclei }\end{array}$ \\
\hline $\begin{array}{l}\text { Azari } \\
\text { et al. [20] }\end{array}$ & Case control & Prefrontal, premotor, parietal & $\begin{array}{l}n=15 \text { young DS, } n=10 \text { older } \\
\text { nondemented DS, } n=4 \\
\text { demented DS and } n=15 \\
\text { young controls }\end{array}$ & $\begin{array}{l}\text { PPVT, MMSE and NINCDS- } \\
\text { ADRDA criteria }\end{array}$ & $\begin{array}{l}\text { Compared with young DS } \\
\text { and old nondemented DS, } \\
\text { old demented DS showed } \\
\text { reduced absolute metabolic } \\
\text { rates in all ROls as well as the } \\
\text { whole-brain. This reduction } \\
\text { was particularly evident in } \\
\text { the left premotor and parietal } \\
\text { lobe }\end{array}$ \\
\hline $\begin{array}{l}\text { Dani } \\
\text { et al. [21] }\end{array}$ & $\begin{array}{l}\text { Longitudinal } \\
\text { cohort study }\end{array}$ & $\begin{array}{l}\text { Parietal, temporal and } \\
\text { sensorimotor primary cortex }\end{array}$ & $\begin{array}{l}n=12 \text { nondemented DS } \\
\text { (aged } 31-59 \text { ) on longitudinal } \\
\text { evaluation } n=2 \text { (aged } 49 \\
\text { and } 50 \text { years) became } \\
\text { demented }\end{array}$ & DSMSE & $\begin{array}{l}\text { The } 2 \text { subjects who became } \\
\text { demented, exhibited a rapid } \\
\text { decline in glucose } \\
\text { metabolism in the parietal } \\
\text { and temporal regions, whilst } \\
\text { the nondemented DS } \\
\text { subjects did not show } \\
\text { changes in glucose } \\
\text { metabolism over the } 7 \text { years }\end{array}$ \\
\hline $\begin{array}{l}\text { Sabbagh } \\
\text { et al. [24] }\end{array}$ & Case control & $\begin{array}{l}\text { Frontal, temporal, parietal, } \\
\text { anterior cingulate, posterior } \\
\text { cingulate and precuneus }\end{array}$ & $\begin{array}{l}n=5 \text { demented DS, } n=12 \\
\text { nondemented DS and } n=9 \\
\text { normal controls }\end{array}$ & $\begin{array}{l}\text { DLD, MMSE), BPT, SIB, the } \\
\text { VABS-second edition }\end{array}$ & $\begin{array}{l}\text { DS demented subject } \\
\text { showed hypometabolism in } \\
\text { posterior cingulate, lateral } \\
\text { parietal, temporal and frontal } \\
\text { regions. Furthermore, } \\
\text { demented DS had lower } \\
\text { glucose metabolic rates in } \\
\text { additional frontal regions } \\
\text { than controls }\end{array}$ \\
\hline
\end{tabular}

Functional Neuroimaging in Down Syndrome with and without Dementia 
Table 1 (continued)

\begin{tabular}{|c|c|c|c|c|c|}
\hline Study & Study design & Region of interest & Cohort & Clinical data & Main findings \\
\hline $\begin{array}{l}\text { Lao et al. } \\
{[25]}\end{array}$ & $\begin{array}{l}\text { Cross- } \\
\text { sectional }\end{array}$ & $\begin{array}{l}\text { Anterior cingulate, frontal } \\
\text { cortex, parietal cortex, } \\
\text { precuneus, striatum, } \\
\text { temporal cortex, } \\
\text { hippocampus }\end{array}$ & $\begin{array}{l}n=16 \text { nondemented DS } \\
\text { (average age } 35 \text { years - PiB- } \\
\text { negative), } n=5 \\
\text { nondemented DS (average } \\
\text { age } 47 \text { years - PiB-positive), } n \\
=3 \text { demented DS (average } \\
\text { age } 49 \text { years) }\end{array}$ & PPVT & $\begin{array}{l}\text { Given small sample of } \\
\text { demented DS ( } n=3) \text {, study } \\
\text { did not have power to } \\
\text { identify differences between } \\
\text { demented and nondemented } \\
\text { DS. Instead used nested } \\
\text { models to demonstrate } \\
\text { influence of nondemented } \\
\text { PiB(+) and demented } \\
\text { individuals on the } \\
\text { associations between A } \beta \\
\text { burden, metabolism, and GM } \\
\text { volume. Overall demented } \\
\text { DS subjects appear to have } \\
\text { negative association with PiB } \\
\text { SUVR, FDG SUVR, and GM } \\
\text { volume }\end{array}$ \\
\hline
\end{tabular}

DS, Down syndrome; PPVT, Peabody Picture Vocabulary Test; DSMSE, Down Syndrome Mental Status Examination; MMSE, Mini Mental State Examination; NINCDS-ADRDA, National Institute of Neurological and Communicative Disorders and Stroke and the Alzheimer's Disease and Related Disorders Association; ROI, region of interest; DLD, Dementia Questionnaire for People with Learning Disabilities; BPT, Brief Praxis Test; SIB, Severe Impairment Battery; VABS, Vineland Adaptive Behavior Scale; PiB, Pittsburgh compound B; A $\beta$, amyloid-beta; SUVR, standard uptake value ratio; GM, gray matter; FDG-PET, fluorodeoxyglucose-positron emission tomography; AD, Alzheimer's disease; CMRglc, cerebral metabolic rate of glucose.

establish reliable cutoff scores in these tests in the first place, given the heterogeneity of intellectual functioning amongst the DS population $[9,10]$. Additionally, individuals with DS are likely to struggle with communication leading the assessor to rely on information provided by family and/or carers to make a diagnosis of dementia which will be subjective and therefore not always reliable. Given this, neuroimaging may present as an objective way in which important information can be obtained to potentially support a diagnosis of dementia in individuals with DS [9].

There are relatively few DS and dementia neuroimaging studies available $[11,12]$. This is thought to be due to the challenges in scanning people with DS and its timeconsuming and costly nature [9]. Additionally, recruitment of adequate numbers of age-matched DS subjects with and without $\mathrm{AD}$, who are also able to tolerate MRI has proved difficult [13]. Furthermore, neuroimaging of DS subjects is associated with high levels of motion artifact which can affect the quality of the images and though sedatives can be used in the general population with regard to scanning, the use of these in the DS population raises an ethical dilemma $[5,14,15]$.

Despite this, neuroimaging may help researchers identify early structural, functional, neurochemical, and metabolic changes which occur with AD in DS, potentially allowing for a better understanding of $\mathrm{AD}$ pathogenesis. This will hopefully lead to a clearer and more effective diagnostic protocol for this population. Furthermore, given the age-dependent neuropathology of $\mathrm{AD}$ in $\mathrm{DS}$, it may also be possible to monitor the progression of $\mathrm{AD}$ in DS longitudinally with neuroimaging focused on particular biomarkers, thereby providing researchers with vital information regarding potential targets for therapeutic intervention even in the preclinical phase $[9,11]$. The aim of this review is to provide an overview of functional neuroimaging studies within this field over the past 80 years or so.

\section{Review}

In order to identify relevant articles on neuroimaging in DS, with and without dementia, we searched the PubMed database until 31 December 2020. All reference lists from any systematic reviews identified in the initial search were hand searched to find any additional studies of interest. We included studies that were in the English language, peer reviewed, and included brain functional neuroimaging conducted in people with DS with any dementia, of any age and from both genders. 
Table 2. MRS studies on DS with and without dementia

\begin{tabular}{|c|c|c|c|c|c|}
\hline Study & Study design & $\begin{array}{l}\text { Region of } \\
\text { interest }\end{array}$ & Cohort & Clinical data & Main findings \\
\hline $\begin{array}{l}\text { Shonk and } \\
\text { ross [33] }\end{array}$ & Case control & $\begin{array}{l}\text { Occipital cortex, } \\
\text { parietal white } \\
\text { matter }\end{array}$ & $\begin{array}{l}n=23 \text { nondemented DS (age } \\
\text { unknown), } n=1 \text { demented DS }\end{array}$ & Not stated & $\begin{array}{l}\text { MI was elevated in nondemented DS } \\
\text { subjects when compared with controls. } \\
\text { MI was further elevated in demented DS } \\
\text { while NAA was found to be decreased }\end{array}$ \\
\hline $\begin{array}{l}\text { Lamar } \\
\text { et al. [8] }\end{array}$ & Case control & Hippocampus & $\begin{array}{l}n=35 \text { demented DS (average age }= \\
52.8 \text { years), } n=18 \text { nondemented DS } \\
\text { (average age } 47.2 \text { years), } n=13 \\
\text { controls (average age } 50.6 \text { years), } n= \\
39 \text { sporadic AD (average age } 76.8 \\
\text { years) }\end{array}$ & CAMCOG & $\begin{array}{l}\text { MI was significantly higher in demented } \\
\text { DS than nondemented DS, controls and } \\
\text { sporadic AD. NAA was significantly } \\
\text { reduced in demented DS compared to } \\
\text { nondemented DS but was similar to } \\
\text { controls }\end{array}$ \\
\hline $\begin{array}{l}\text { Tan } \\
\text { et al. [35] }\end{array}$ & Case control & Hippocampus & $\begin{array}{l}n=35 \text { nondemented DS (average age } \\
35 \text { years), } n=11 \text { demented DS } \\
\text { (average age } 52 \text { years) and } n=39 \\
\text { controls (average age } 35 \text { years) }\end{array}$ & CAMCOG & $\begin{array}{l}\text { There was no significant difference in } \\
\text { the hippocampal Glx concentration } \\
\text { between demented DS and } \\
\text { nondemented DS, or between either of } \\
\text { the DS groups and the healthy controls }\end{array}$ \\
\hline $\begin{array}{l}\text { Lin } \\
\text { et al. [34] }\end{array}$ & Case control & $\begin{array}{l}\text { Posterior } \\
\text { cingulate cortex }\end{array}$ & $\begin{array}{l}n=22 \text { nondemented DS (average age } \\
46.7 \text { years), } n=5 \text { demented DS } \\
\text { (average age } 53.7 \text { years), } n=15 \text { control } \\
\text { (average age } 47.8 \text { years) }\end{array}$ & $\begin{array}{l}\text { BPT, SIB, Dementia } \\
\text { Questionnaire for } \\
\text { Persons with Mental } \\
\text { Retardation (DMR) } \\
\text { and NINCDS-ADRDA } \\
\text { criteria }\end{array}$ & $\begin{array}{l}\text { NAA and GIx were significantly lower in } \\
\text { demented DS subjects than } \\
\text { nondemented DS and healthy controls. } \\
\text { MI increased in DS when compared with } \\
\text { controls but not further increased in } \\
\text { demented DS }\end{array}$ \\
\hline
\end{tabular}

DS, Down syndrome; MI, myoinositol; NAA, N-acetylaspartate; CAMCOG, Cambridge Cognition Examination; AD, Alzheimer's dementia; GIx, glutamateglutamine complex; BPT, Brief Praxis Test; SIB, Severe Impairment Battery; DMR, Dementia Questionnaire for Persons with Mental Retardation; NINCDSADRDA, National Institute of Neurological and Communicative Disorders and Stroke and the Alzheimer's Disease and Related Disorders Association; MRS, magnetic resonance spectroscopy.

We identified 7 studies that investigated brain metabolism using fluorodeoxyglucose-positron emission tomography (FDG-PET) (Table 1), 4 which investigated brain neurochemistry using magnetic resonance spectroscopy (MRS) (Table 2) and 4 which investigated amyloid accumulation within the brain using ligand-based PET (Table 3). All studies sought to compare DS patients with dementia to those without dementia.

\section{FDG-PET Studies}

FDG-PET studies have been vital in the assessment of brain metabolism in $\mathrm{AD}$ and DS. Research indicates that reductions in regional brain metabolism are evident in $\mathrm{AD}$ and that these reductions are roughly proportional to the severity of the dementia. In DS subjects with dementia, these reductions appear to be greater in the association sensory and motor neocortical regions (as opposed to the primary regions) and correlate with cognitive decline, neuropathology, and neuronal loss $[9,16,17]$.

Regarding the 7 studies which investigated brain metabolism, DS subjects with dementia demonstrated glucose hypometabolism relative to nondemented DS sub- jects or controls within the same brain regions (see Table 1). In a study from the 1980s, age-related declines in brain metabolism were found in the middle-aged nondemented DS subjects whilst further reductions were observed in the demented DS subjects [18]. A 1988 case report revealed the cerebral metabolic rate of glucose (CMRglc) to be $28 \%$ less in an older DS subject with dementia than young nondemented DS subjects and significant glucose hypometabolism was noted in the parietal and temporal lobe association cortices in particular [19]. Older DS subjects with dementia have demonstrated the same pattern of abnormal glucose metabolism as seen in subjects with $\mathrm{AD}$, where newer association areas of parietal and temporal neocortices are mainly affected but there is relative sparing of the primary sensorimotor neocortex, cerebellum, thalamus, and caudate and lenticular nuclei [4]. Compared with young nondemented DS subjects and old nondemented DS subjects, old DS subjects with dementia showed reduced absolute metabolic rates in the association prefrontal, premotor, and parietal regions well as in the whole-brain, again supporting the findings of earlier studies [20]. 
Table 3. Ligand-based PET studies on DS with and without dementia

\begin{tabular}{|c|c|c|c|c|c|}
\hline Study & Study design & Region of interest & Cohort & Clinical data & Main findings \\
\hline $\begin{array}{l}\text { Landt } \\
\text { et al. [5] }\end{array}$ & Case control & $\begin{array}{l}\text { Anterior cingulate, } \\
\text { calcarine, hippocampus, } \\
\text { posterior cingulate, } \\
\text { prefrontal, superior parietal }\end{array}$ & $\begin{array}{l}n=9 \text { DS (aged } 25-64 \text { and of } \\
\text { whom } n=5 \text { had a diagnosis } \\
\text { of AD), } n=14 \text { non-demented } \\
\text { healthy controls (aged 33-69 }\end{array}$ & $\begin{array}{l}\text { CAMDEX-R, } \\
\text { Gregory and } \\
\text { Hodges criteria }\end{array}$ & $\begin{array}{l}\text { When compared with the healthy } \\
\text { controls, only participants with DS older } \\
\text { than } 45 \text { years showed significant PiB } \\
\text { binding usually associated with } A D \text {, } \\
\text { regardless of a dementia diagnosis or } \\
\text { not }\end{array}$ \\
\hline $\begin{array}{l}\text { Mak } \\
\text { et al. [44] }\end{array}$ & Case report & $\begin{array}{l}\text { Precuneus, striatum, } \\
\text { frontoparietal cortices, } \\
\text { temporal lobes }\end{array}$ & $\begin{array}{l}n=1 . \text { Age }=40 \text { on } \\
\text { recruitment (nondemented } \\
\text { DS with } \mathrm{MCl} \text { who later } \\
\text { developed dementia during } \\
\text { the 7-year follow-up) }\end{array}$ & $\begin{array}{l}\text { CAMDEX-DS, } \\
\text { CAMCOG }\end{array}$ & $\begin{array}{l}\text { Baseline scan showed elevated PiB } \\
\text { binding (amyloid-beta plaque). } 2 \text { years } \\
\text { prior to onset of dementia sharp } \\
\text { increase in PiB binding seen in fronto- } \\
\text { patietal cortices. At onset of dementia } \\
\text { PiB binding plateaued. }\left[{ }^{18} \mathrm{~F}\right]-\mathrm{AV} 1451 \\
\text { (tacau binder) binding elevated in } \\
\text { bilateral precuneus and } \\
\text { temporoparietal cortices after dementia } \\
\text { onset but striatum was relatively spared }\end{array}$ \\
\hline $\begin{array}{l}\text { Wilson } \\
\text { et al. [45] }\end{array}$ & Cross-sectional & - & $\begin{array}{l}n=34 \text { total (19 PiB-negative } \\
\text { and } 15 \text { PiB-positive) }\end{array}$ & $\begin{array}{l}\text { CAMDEX-DS, } \\
\text { CAMCOG-DS }\end{array}$ & $\begin{array}{l}\text { No significant difference in IQ between } \\
\text { PiB +ve and PiB -ve DS participants. } 3 \\
\text { PiB - ve had dementia and } 5 \text { PiB +ve } \\
\text { had dementia }\end{array}$ \\
\hline
\end{tabular}

DS, Down syndrome; CAMDEX-R, Cambridge Mental Disorders of the Elderly Examination - Revised; PiB, Pittsburgh compound B; AD, Alzheimer's dementia; CAMCOG, Cambridge Cognition Examination; $\mathrm{MCl}$, mild cognitive impairment; PET, positron emission tomography.

In a longitudinal study of 12 DS subjects, 2 of the DS subjects had relatively stable brain function prior to developing dementia, after which both glucose metabolism and cognitive function demonstrated rapid decline, whilst the DS subjects who did not develop dementia showed no such decline [21]. Interestingly, with regard to the 2 DS subjects (who eventually developed dementia), nonmemory cognitive function showed a stable phase lasting at least 7 years preceding dementia, followed by a linear decline following its onset. Additionally, data indicated that changes in glucose metabolism followed a similar bilinear decline; with the onset of dementia characterized by nonmemory cognitive functions in the first phase. This suggests that a subtle neocortical metabolic decline may precede neocortical (nonmemory) cognitive abnormalities, thus medical intervention at this stage may slow disease progression and therefore may delay the clinical manifestations of dementia [21].

Significantly lower CMRglc bilaterally in DS subjects with dementia has been demonstrated in the posterior cingulate, lateral parietal, temporal, and frontal regions, compared with nondemented DS subjects and healthy controls have been previously shown to be preferentially affected in the clinical and preclinical stages of late-onset $\mathrm{AD}[22,23]$. Overall, the DS subjects showed lower CMRglc than the healthy controls in additional frontal regions, whether they had dementia or not, although this was thought to reflect differences in brain development [24]. A more recent study was unable to identify statistically significant differences between the nondemented DS subjects and the DS subjects with dementia due to lack of power; however, with the use of nested models, it showed that the DS subjects with dementia demonstrated glucose hypometabolism within the anterior cingulate, frontal cortex, parietal cortex, precuneus, striatum, temporal cortex, and hippocampus regions which cannot be explained solely by reduction in gray matter volume [25]. Interestingly, other studies have reported increased inferior and medial temporal region CMRglc in middle-aged nondemented DS subjects, raising the possibility that compensatory mechanisms are initiated and local neuronal activity is therefore increased in the early stages of $\mathrm{AD}$ $[17,24,26]$. It is clear that further research is required on this. 
All studies consistently showed glucose hypometabolism specifically within the parietal and/or temporal regions (with 4 of them demonstrating marked glucose hypometabolism within these regions) indicting that these regions are likely affected first in the preclinical stages of $\mathrm{AD}$. It is therefore reasonable to suggest that FDG-PET imaging may prove useful in detecting preclinical dementia in the DS population but further studies are required.

\section{MRS Studies}

Proton MRS ( $\left.{ }^{1} \mathrm{H}-\mathrm{MRS}\right)$ can be used to measure in vivo brain concentrations of glutamate-glutamine complex (Glx), myoinositol (MI), N-acetylaspartate (NAA) (a marker of neuronal density and/or mitochondrial function), choline-containing compounds (a measure of membrane synthesis/turnover), and creatine and phosphocreatine (a measure of cellular energy metabolism) [27-29]. Specifically, NAA and Glx decrease and MI increase correlate with both aging and $\mathrm{AD}$, thus ${ }^{1} \mathrm{H}-\mathrm{MRS}$ is widely used to characterize the neurochemistry of brain health and disease $[30,31]$. Additionally, the ratio of NAA to $\mathrm{MI}$ can also be used to distinguish nondemented from demented people [32].

DS subjects with dementia showed significantly higher MI levels with lower levels of NAA in the hippocampus, than nondemented DS subjects and healthy controls [8]. A 1995 case report showed that a DS subject with dementia had elevated MI levels and reduced NAA levels when compared with 23 nondemented DS subjects [33]. These results have again been demonstrated by a more recent study, where DS subjects with dementia showed reduced levels of NAA and Glx within the posterior cingulate cortex, when compared with nondemented DS subjects and healthy controls, but increased levels of MI [34]. Interestingly there was no significant difference in the levels of $\mathrm{Cr}+\mathrm{PCr}$ or Cho between DS subjects with dementia, nondemented DS subjects and healthy controls nor was there any significant difference in hippocampal Glx concentration between DS subjects with dementia and nondemented DS subjects [8]. Furthermore, there was no correlation between hippocampal Glx concentration, cognitive ability and memory as measured by the Cambridge Cognition Examination (CAMCOG) scores in either of the DS groups [35].

It appears that ${ }^{1} \mathrm{H}$-MRS provides useful information with regard to changes in neuronal biomarkers implicated in AD in DS. In 3 out of the 4 studies, increased MI and decreased NAA were consistently observed in DS subjects with dementia when compared with nondemented DS subjects notably within the hippocampus, posterior cin-

Functional Neuroimaging in Down Syndrome with and without Dementia gulate cortex, occipital cortex and parietal white matter. Given this, further studies investigating the link between these biomarkers, cognition, and different regions of the brain may provide researchers with targets for early therapeutic interventions.

\section{Ligand-Based PET Studies}

Post-mortem studies have shown that by the age of 40 years, DS subjects show neuropathologic changes (i.e., neurofibrillary tangles and amyloid plaques) consistent with a diagnosis of $\mathrm{AD}[3]$. Pittsburgh compound $\mathrm{B}(\mathrm{PiB})$ is used to assess amyloid accumulation in $\mathrm{AD}$. PiB specifically binds to amyloid arranged in beta sheets in classic plaques, cerebrovascular amyloid angiopathy, and to a lesser extent, diffuse plaques [9,36-38].

In a case control study of 9 subjects with DS and 14 healthy controls, it was shown that when compared with healthy controls, only DS subjects older than 45 years showed significant $\mathrm{PiB}$ binding usually associated with $A D$, regardless of a dementia diagnosis or not [5]. The study unfortunately did not comment specifically on any differences (or lack of) between the PiB binding observed in the DS subjects with dementia and the nondemented DS subjects. The researchers also expressed caution over generalizing their results due to the small sample size.

Nondemented DS subjects exhibited PiB binding in significantly fewer regions in comparison with DS subjects with dementia [39]. Studies have demonstrated that amyloid accumulation first occurs, in DS subjects, in the striatum at around age 40 years followed by the rostral prefrontal-cinguloparietal regions, then caudal frontal, rostral temporal, primary sensorimotor and occipital regions, and lastly the mediotemporal regions and remainder of the basal ganglia $[9,39-43]$. It has been suggested that initial amyloid deposition triggers a process whereby amyloid accumulates, reaches a steady state and subsequently elicits a chain of events leading to synaptic dysfunction, neuronal loss, and dementia [8].

A more recent case report suggests a sharp increase in $\mathrm{PiB}$ binding is detectable prior to the clinical onset of dementia in DS, particularly in the precuneus and striatum, and there is also a sharp rise in $\mathrm{PiB}$ binding in the frontoparietal cortices during this time, but this eventually plateaus on follow-up imaging [44]. Another study categorized DS participants as either PiB-positive or PiB-negative and found that clinical correlation for dementia identified 3 PiB-negative participants were demented and $5 \mathrm{PiB}$-positive participants were demented highlighting that amyloid deposition alone may not to blame for dementia in DS [45]. Interestingly, one study revealed $\mathrm{PiB}$ 
binding is increased in the anterior cingulate cortex, frontal cortex, and striatum when compared to controls though PiB binding is globally increased when comparing demented DS participants to nondemented DS participants [25]. A recent review concluded that age of onset of amyloid deposition precedes onset of DS dementia, and the use of amyloid PET is effective in identifying older subjects with substantial fibrillar $\mathrm{A} \beta$ deposition making it a valuable biomarker for classic $\mathrm{AD}$ amyloid pathology in these people, however, utility of amyloid PET may be limited in the earliest stages of the natural history of amyloid in DS subjects younger than 25 years [46]. It is clear that further research is required to fully explore the role of striatal amyloid accumulation in the early pathogenesis of $\mathrm{AD}$ and to investigate the link between amyloid accumulation and cognitive decline.

\section{Discussion}

This is one of the few reviews carried out to investigate functional neuroimaging in DS with and without dementia. The FDG-PET studies all consistently demonstrated reduced glucose metabolism in the brain of DS subjects with dementia when compared with nondemented DS subjects, with 4 out of the 7 studies specifically identifying marked glucose hypometabolism within the parietal and/or temporal lobe. Three out of the 4 MRS studies showed increased MI and decreased NAA in DS subjects with dementia when compared with nondemented DS subjects notably within the hippocampus, posterior cingulate cortex, occipital cortex, and parietal white matter. The fourth study only investigated the biomarker Glx, commenting that there was no difference between the hippocampal Glx concentration of DS subjects with dementia and nondemented DS subjects. However, interestingly, one of the other MRS studies which investigated posterior cingulate cortex Glx concentration found it to be significantly lower in DS subjects with dementia than nondemented DS subjects [34]. The ligand-based PET studies indicated significant PiB binding in DS subjects over the age of 40 years, particularly if they had dementia. Of note, Annus et al. [39] did not detect any abnormal binding in the hippocampus while Landt et al. [5] found that out of all the regions of interest, the hippocampus showed the least PiB binding. Further research on this may help provide a better understanding of the amyloid accumulation process and potential stages for therapeutic intervention.
Neuroimaging is a potential tool for monitoring biomarkers and changes in brain morphology associated with progression from preclinical to symptomatic dementia in DS but it does present with limitations. It is important to note that brain changes noted on ligandbased PET may occur too late for effective intervention, so other neuroimaging modalities such as FDG-PET may actually prove to be more useful with regard to revealing early brain changes [9].

The DS brain differs from the non-DS brain even in the absence of dementia so this must be kept in mind when collating and interpreting any data obtained from neuroimaging $[9,43]$. Longitudinal studies may be helpful in distinguishing changes in the brain due to dementia alone from other causes, such as age-associated changes. Another limitation is that some changes occurring to the brain may not be detectable by neuroimaging until the disease has progressed significantly, therefore potentially limiting its use in the preclinical phase where the individual's level of functioning and cognition still permits a good quality of life.

In studies involving people with DS, the sample sizes tend to be smaller. This can make it difficult to determine whether certain results are statistically significant or not. Sample sizes can be small for a number of reasons. First, recruitment is generally difficult with regard to neuroimaging studies due to people's fear of being scanned [47]. Second, people with DS tend to have a higher prevalence of obesity which in itself can lead to discomfort in the scanner, potentially precluding them from participating in neuroimaging studies $[11,48]$. Third, it may be more difficult for people with DS (especially those with dementia and older in age) to understand and comply with instructions and remain motionless during the scanning process leading to artifact [9]. Additionally, the unique structure of the neck and face in DS individuals means it can be quite uncomfortable for them to remain in the prone position for considerable lengths of time [11].

Sedative medication can be administered to help relax the participants, but this carries its own ethical implications and the sedatives themselves can directly affect the functional measures that are being investigated, leading to skewed results $[5,11]$. It would be prudent, in the first instance, to allow the DS participants the opportunity to visit the scanning site and become familiar with the scanning process. This would hopefully cause a strong trust relationship to develop between the researchers and participants, causing the latter to feel more relaxed and more likely to comply adequately with the entire process, thus avoiding the need for sedation. Utilizing mock scanners
Deinde/Kotecha/Lau/Bhattacharyya/ Velayudhan 
and reducing scan waiting times may also prove helpful in putting participants at ease.

It is important to note that neuroimaging is costlier and more time-consuming than other clinical tests such as psychiatric assessments, thus limiting its feasibility as a widespread diagnostic tool [9]. Neuroimaging may be more beneficial when used in conjunction with cognitive and clinical assessments.

Though not covered in this review, structural neuroimaging studies investigating DS subjects with and without dementia may yield further useful information. It will allow researchers to identify which specific brain regions undergo atrophy and other physical changes and how these relate to cognitive decline, abnormal PiB binding as well as metabolic and biochemical changes. This will hopefully lead to better diagnostic protocols and therapeutic interventions.

In conclusion, neuroimaging is a powerful tool which may aid researchers in the detection of early structural, functional, neurochemical, and metabolic changes which occur with $\mathrm{AD}$ in $\mathrm{DS}$, allowing clinicians to intervene in high-risk patients prior to disease progression thereby preserving cognition function and a good quality of life. There are no preventative treatments for $\mathrm{AD}$ and current treatments are mainly aimed at managing symptoms. Data obtained from neuroimaging in this population may aid in the development of novel treatments and allow for the efficacy of the same to be monitored. More longitudinal studies with large sample sizes will be vital in increas- ing our understanding of the pathogenesis of $\mathrm{AD}$ in $\mathrm{DS}$ and tracking the disease's course, improving outcomes within this specific population.

\section{Statement of Ethics}

Ethical approval was not required.

\section{Conflict of Interest Statement}

The authors report no conflict of interest.

\section{Funding Sources}

The authors report that Cardiff University covered the costs of the article publication fee.

\section{Author Contributions}

F.D. contributed to literature search, data extraction, and writing the initial manuscript. J.K. contributed to literature search, data extraction, and writing the manuscript. L.S.L.L. contributed to literature search and data extraction. S.B. contributed to conceptualization, supervision of data extraction, and provided critical comments on the manuscript. L.V. contributed to conceptualization, literature search, supervision of data extraction, provided critical comments on the manuscript, and finalized the manuscript.

\section{References}

1 Ballard C, Mobley W, Hardy J, Williams G, Corbett A. Dementia in Down's syndrome. Lancet Neurol. 2016;15(6):622-36.

2 Prasher VP, Sachdeva N, Tarrant N. Diagnosing dementia in adults with Down's syndrome. Neurodegener Dis Manag. 2015;5(3): $249-56$.

3 Teipel SJ, Hampel H. Neuroanatomy of Down syndrome in vivo: a model of preclinical Alzheimer's disease. Behav Genet. 2006; 36(3):405-15.

4 Schapiro MB, Haxby JV, Grady CL. Nature of mental retardation and dementia in Down syndrome: study with PET, CT, and neuropsychology. Neurobiol Aging. 1992;13(6): 723-34.

5 Landt J, D'Abrera JC, Holland AJ, Aigbirhio FI, Fryer TD, Canales R, et al. Using positron emission tomography and carbon 11-labeled Pittsburgh compound B to image brain fibrillar beta-amyloid in adults with down syndrome: safety, acceptability, and feasibility. Arch Neurol. 2011;68(7):890-6.
6 Head E, Powell D, Gold BT, Schmitt FA. Alzheimer's disease in Down syndrome. Eur J Neurodegener Dis. 2012;1(3):353-64.

7 Jennings D, Seibyl J, Sabbagh M, Lai F, Hopkins W, Bullich S, et al. Age dependence of brain beta-amyloid deposition in Down syndrome: an [18F]florbetaben PET study. Neurology. 2015;84(5):500-7.

8 Lamar M, Foy CML, Beacher F, Daly E, Poppe $\mathrm{M}$, Archer N, et al. Down syndrome with and without dementia: an in vivo proton Magnetic Resonance Spectroscopy study with implications for Alzheimer's disease. Neuroimage. 2011;57(1):63-8.

9 Neale N, Padilla C, Fonseca LM, Holland T, Zaman S. Neuroimaging and other modalities to assess Alzheimer's disease in Down syndrome. Neuroimage Clin. 2018;17:263-71.

10 Sabbagh M, Edgin J. Clinical assessment of cognitive decline in adults with Down syndrome. Curr Alzheimer Res. 2016;13(1):30-4.
11 Head E, Powell DK, Schmitt FA. Metabolic and vascular imaging biomarkers in Down syndrome provide unique insights into brain aging and Alzheimer disease pathogenesis. Front Aging Neurosci. 2018;10:191.

12 Mullins D, Daly E, Simmons A, Beacher F, Foy CM, Lovestone $S$, et al. Dementia in Down's syndrome: an MRI comparison with Alzheimer's disease in the general population. J Neurodev Disord. 2013;5(1):19.

13 Beacher F, Daly E, Simmons A, Prasher V, Morris R, Robinson C, et al. Alzheimer's disease and Down's syndrome: an in vivo MRI study. Psychol Med. 2009;39(4):675-84

14 Anderson JS, Nielsen JA, Ferguson MA, Burback MC, Cox ET, Dai L, et al. Abnormal brain synchrony in Down syndrome. Neuroimage Clin. 2013;2:703-15.

15 Bletsch A, Mann C, Andrews DS, Daly E, Tan GMY, Murphy DGM, et al. Down syndrome is accompanied by significantly reduced cortical grey-white matter tissue contrast. Hum Brain Mapp. 2018;39(10):4043-54.
Functional Neuroimaging in Down Syndrome with and without Dementia
Dement Geriatr Cogn Disord Extra 2021;11:324-332 DOI: $10.1159 / 000520880$ 
16 Rapoport SI. Positron emission tomography in Alzheimer's disease in relation to disease pathogenesis: a critical review. Cerebrovasc Brain Metab Rev. 1991;3(4):297-335.

17 Haier RJ, Head K, Head E, Lott IT. Neuroimaging of individuals with Down's syndrome at-risk for dementia: evidence for possible compensatory events. Neuroimage. 2008; 39(3):1324-32.

18 Cutler NR. Cerebral metabolism as measured with positron emission tomography (PET) and $[18 \mathrm{~F}]$ 2-deoxy-D-glucose: healthy aging, Alzheimer's disease and Down syndrome. Prog Neuropsychopharmacol Biol Psychiatry. 1986;10(3-5):309-21.

19 Schapiro MB, Ball MJ, Grady CL, Haxby JV, Kaye JA, Rapoport SI. Dementia in Down's syndrome: cerebral glucose utilization, neuropsychological assessment, and neuropathology. Neurology. 1988;38(6):938-42.

20 Azari NP, Pettigrew KD, Pietrini P, Horwitz B, Schapiro MB. Detection of an Alzheimer disease pattern of cerebral metabolism in Down syndrome. Dementia. 1994;5(2):6978.

21 Dani A, Pietrini P, Furey M, McIntosh A, Grady C, Horwitz B, et al. Brain cognition and metabolism in Down syndrome adults in association with development of dementia. Neuroreport. 1996;7(18):2933-6.

22 Alexander GE, Chen K, Pietrini P, Rapoport SI, Reiman EM. Longitudinal PET evaluation of cerebral metabolic decline in dementia: a potential outcome measure in Alzheimer's disease treatment studies. Am J Psychiatry. 2002;159(5):738-45.

23 Reiman EM, Chen K, Alexander GE, Caselli RJ, Bandy D, Osborne D, et al. Functional brain abnormalities in young adults at genetic risk for late-onset Alzheimer's dementia. Proc Natl Acad Sci U S A. 2004;101(1):284-9.

24 Sabbagh MN, Chen K, Rogers J, Fleisher AS, Liebsack C, Bandy D, et al. Florbetapir PET, FDG PET, and MRI in Down syndrome individuals with and without Alzheimer's dementia. Alzheimers Dement. 2015;11(8):9941004.

25 Lao PJ, Handen BL, Betthauser TJ, Mihaila I, Hartley SL, Cohen AD, et al. Alzheimer-like pattern of hypometabolism emerges with elevated amyloid-beta burden in Down syndrome. J Alzheimers Dis. 2018;61(2):631-44.

26 Head E, Lott IT, Patterson D, Doran E, Haier RJ. Possible compensatory events in adult Down syndrome brain prior to the development of Alzheimer disease neuropathology: targets for nonpharmacological intervention. J Alzheimers Dis. 2007;11(1):61-76.
27 Beacher F, Simmons A, Daly E, Prasher V, Adams C, Margallo-Lana ML, et al. Hippocampal myo-inositol and cognitive ability in adults with Down syndrome: an in vivo proton magnetic resonance spectroscopy study. Arch Gen Psychiatry. 2005;62(12):1360-5.

28 Bates TE, Strangward M, Keelan J, Davey GP, Munro PM, Clark JB. Inhibition of N-acetylaspartate production: implications for $1 \mathrm{H}$ MRS studies in vivo. Neuroreport. 1996;7(8): 1397-400.

29 Miller BL. A review of chemical issues in $1 \mathrm{H}$ NMR spectroscopy: N-acetyl-L-aspartate, creatine and choline. NMR Biomed. 1991; $4(2): 47-52$

30 Parnetti L, Tarducci R, Presciutti O, Lowenthal DT, Pippi M, Palumbo B, et al. Proton magnetic resonance spectroscopy can differentiate Alzheimer's disease from normal aging. Mech Ageing Dev. 1997;97(1):9-14.

31 Lin AL, Rothman DL. What have novel imaging techniques revealed about metabolism in the aging brain? Future Neurol. 2014;9(3): 341-54.

32 Lin A, Ross BD, Harris K, Wong W. Efficacy of proton magnetic resonance spectroscopy in neurological diagnosis and neurotherapeutic decision making. NeuroRx. 2005;2(2): 197-214.

33 Shonk T, Ross BD. Role of increased cerebral myo-inositol in the dementia of Down syndrome. Magn Reson Med. 1995;33(6):85861.

34 Lin AL, Powell D, Caban-Holt A, Jicha G, Robertson W, Gold BT, et al. (1)H-MRS metabolites in adults with Down syndrome: effects of dementia. Neuroimage Clin. 2016;11: 728-35.

35 Tan GM, Beacher F, Daly E, Horder J, Prasher V, Hanney ML, et al. Hippocampal glutamate-glutamine $(\mathrm{Glx})$ in adults with Down syndrome: a preliminary study using in vivo proton magnetic resonance spectroscopy ((1) H MRS). J Neurodev Disord. 2014;6(1):42.

36 Lockhart A, Lamb JR, Osredkar T, Sue LI, Joyce JN, Ye L, et al. PIB is a non-specific imaging marker of amyloid-beta (Abeta) peptide-related cerebral amyloidosis. Brain. 2007 Oct; 130(Pt 10):2607-15.

37 Cohen AD, Rabinovici GD, Mathis CA, Jagust WJ, Klunk WE, Ikonomovic MD. Using Pittsburgh compound B for in vivo PET imaging of fibrillar amyloid-beta. Adv Pharmacol. 2012;64:27-81.

38 LeVine H 3rd, Spielmann HP, Matveev S, Cauvi FM, Murphy MP, Beckett TL, et al. Down syndrome: age-dependence of $\mathrm{PiB}$ binding in postmortem frontal cortex across the lifespan. Neurobiology of Aging. 2017;54: 163-9.
39 Annus T, Wilson LR, Hong YT, Acosta-Cabronero J, Fryer TD, Cardenas-Blanco A, et al. The pattern of amyloid accumulation in the brains of adults with Down syndrome. Alzheimers Dement. 2016;12(5):538-45.

40 Handen BL, Cohen AD, Channamalappa U, Bulova P, Cannon SA, Cohen WI, et al. Imaging brain amyloid in nondemented young adults with Down syndrome using Pittsburgh compound B. Alzheimers Dement. 2012;8(6): 496-501.

41 Lao PJ, Betthauser TJ, Hillmer AT, Price JC, Klunk WE, Mihaila I, et al. The effects of normal aging on amyloid- $\beta$ deposition in nondemented adults with Down syndrome as imaged by carbon 11-labeled Pittsburgh compound B. Alzheimers Dement. 2016;12(4): 380-90.

42 Lao PJ, Handen BL, Betthauser TJ, Mihaila I, Hartley SL, Cohen AD, et al. Longitudinal changes in amyloid positron emission tomography and volumetric magnetic resonance imaging in the nondemented Down syndrome population. Alzheimers Dement. 2017;9:1-9.

43 Annus T, Wilson LR, Acosta-Cabronero J, Cardenas-Blanco A, Hong YT, Fryer TD, et al. The Down syndrome brain in the presence and absence of fibrillar beta-amyloidosis. Neurobiol Aging. 2017;53:11-9.

44 Mak E, Bickerton A, Padilla C, Walpert MJ, Annus T, Wilson LR, et al. Longitudinal trajectories of amyloid deposition, cortical thickness, and tau in Down syndrome: a deep-phenotyping case report. Alzheimers Dement. 2019;11:654-8.

45 Wilson LR, Vatansever D, Annus T, Williams GB, Hong YT, Fryer TD, et al. Differential effects of Down's syndrome and Alzheimer's neuropathology on default mode connectivity. Hum Brain Mapp. 2019;40(15):4551-63.

46 Abrahamson EE, Head E, Lott IT, Handen BL, Mufson EJ, Christian BT, et al. Neuropathological correlates of amyloid PET imaging in Down syndrome. Dev Neurobiol. 2019;79(7): 750-66.

47 Enders J, Zimmermann E, Rief M, Martus P, Klingebiel R, Asbach P, et al. Reduction of claustrophobia during magnetic resonance imaging: methods and design of the "CLAUSTRO” randomized controlled trial. BMC Med Imaging. 2011;11:4.

48 Melville CA, Cooper SA, McGrother CW, Thorp CF, Collacott R. Obesity in adults with Down syndrome: a case-control study. J Intellect Disabil Res. 2005;49(Pt 2):125-33. 